\title{
REPRESENTAÇÕES POÉTICAS DAS ÁGUAS AMAZÔNICAS
}

\author{
Josebel Akel Fares
}

RESUMO: This article argument is centered in the construction of the Amazonian representations, based on the water metaphors. I present a repertoire of texts of the oral and written literature, to expound the aquonarratives - a term used by the professor Paulo Nunes (2001), concerning the works of the writer Dalcídio Jurandir. Thus, I begin by the water images in Caminha's letter - “Waters are so much: infinite" - and I go on the exposition with the metaphors of the river as Amazonic ruin, by Euclides da Cunha (1999), the river slaves, by Edison Carneiro (1946), the water dictatorship, by Giovanni Gallo (1980), the water as Amazonic clock, by Raymundo Morais (1936), the water nation, by Tiago Mello (2002), the river as a street, by Ruy Barata (ano?). And still, the cosmogonies which translate the inescapable condition of the waters, as the narratives of toco, listened in Marajó island, and the pororoca origin.

PALAVRAS-CHAVE: Amazônia, água, poéticas.

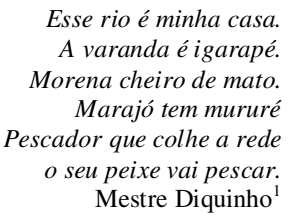

O território amazônico situa-se ao norte da América do Sul e compõe-se de mais de $50 \%$ do território brasileiro, da Venezuela, da Colômbia, da República da Guiana, da Bolívia, do Peru, do Equador, do Suriname e da Guiana Francesa, os quatro últimos na sua totalidade territorial. Os países

Professora adjunta do Departamento de Arte e do Programa de Pós Graduação em Educação (Mestrado) da UEPA, de Cultura e Literatura de Expressão Amazônica, do curso de Licenciatura em Letras da UNAMA. Mestre em Teoria Literária (UFPA) e Doutora em Comunicação e Semiótica (PUC/SP). Coordenadora do Grupo de Estudos e Pesquisa "Culturas e Memórias Amazônicas" /CNPQ - UEPA, participante dos Núcleo das Poéticas da Oralidade (PUC-SP); Núcleo de educação popular (UEPA); Estudos de Narrativas na Amazônia (UFPA) e do GT de Literatura Oral e Popular da ANPOLL. Desenvolve projeto de pesquisa e extensão ligado à Memória de Belém, é pesquisadora das poéticas amazônicas. Publicou os didáticos "Texto e Pretexto" (3 ed./ Semec; Cejup) e "Do Texto ao Texto" (Seduc), em co-autoria com Josse Fares, Paulo Nunes entre outros.

1"Meu nome é Raimundo Miranda e sou conhecido como mestre Diquinho. Sou natural de Soure, sou marajoara da gema, graças a Deus e estou aqui à sua disposição. Eu sou pescador, artesão, pinto um pouco, confecciono, um pouco, com argila, talha também, faço também comédia de boi-bumbá, já fui campeão aqui em Soure. Sou, sou campeão de samba enredo também. [...] De todas essas coisas, o que eu gosto mais de fazer é fazer letra e cantar, eu gosto muito. Eu acordo, às vezes, cantando. Música pra mim é assim, eu acordo, às vezes, cantando. Acordo com a melodia e a música na cabeça. Ninguém me ensinou, graças a Deus, é um dom que vem de Deus. [...] Hoje estou no Cruzeirinho fazendo música de carimbó com muito orgulho, graças a Deus". Os versos fazem parte da letra Viva a Cidade de Soure, gravada em CD pelo Grupo de Tradições Marajoara Cruzeirinho (2000). 
amazônicos guardam marcas de um passado e de um presente que, ao mesmo tempo, os assemelham e os diferenciam. A situação econômica e política, o processo de colonização, a religiosidade, as línguas são alguns desses fatores de proximidade e distanciamento entre eles.

A Amazônia Brasileira é formada pelos Estados do Pará, Amazonas, Acre, Amapá, Rondônia, Roraima, Tocantins, Mato Grosso, parte do Maranhão e Goiás, explicam os livros de geografia. As áreas verdes, a grande bacia hidrográfica, as altas temperaturas e o clima úmido transformam a natureza amazônica em um paraíso de biodiversidade. A maior região brasileira em extensão territorial é, contudo, a menos habitada. Grande parte da população localiza-se na área urbana das cidades e nas capitais, o que agrava a situação de despovoamento.

A grandeza amazônica é definida pela fisiografia. Os mapas desenham o espaço com grandes áreas de floresta, com a rede fluvial e, na seca, com as ranhuras do solo. Neste estudo, apresento algumas poéticas influenciadas pelo espaço amazônico, centradas em imagens da água.

A água metaforiza a erotização primordial: a água da concepção, onde nada o sêmen que origina a vida; a água maternal do ventre, onde o homem mergulha pela primeira vez, e a água láctea, o alimento primeiro - elementos propiciadores das sensações de segurança e proteção, que estabelecem uma relação do mundo interior com o mundo exterior. Na pia batismal, a água permite ao homem a purificação das culpas e dos pecados de um estágio anterior - como as águas do dilúvio - e simboliza a admissão no mundo místico, o renascimento. $\mathrm{O}$ corpo humano compõe-se de alto percentual de água, por isso, às vezes, como as marés, o homem é tão susceptível aos movimentos lunares. A água é a origem de todas as coisas, assegura Tales, o primeiro filósofo.

As águas podem originar-se de fontes celestes ou terrestres. As águas da chuva fertilizam e fecundam a terra, no entanto, também podem ser responsáveis pelas enchentes, inundações. As águas brotadas ou acumuladas podem significar os perigos dos oceanos, dos rios, dos lagos.

A imensidão das águas é uma marca característica da natureza brasileira, destacada já na carta de Pero Vaz de Caminha, escrita no século XVI. Ao comentar sobre as belezas naturais da terra encontrada, o escrevente constrói o espaço com um léxico relativo às águas. Praia, rio de água doce, ribeira, lagoa, ilhéus referem-se à possibilidade de prosperidade. "Águas são muitas: infindas. E em tal maneira é graciosa que, querendo-a aproveitar, dar-se-á nela tudo, por bem das águas que tem”. A carta, de certa forma, profetiza. Todavia, tanto a ausência quanto a abundância do líquido trazem problemas, inviabilizam ou dificultam a vida. As Regiões Norte e Nordeste, especialmente, padecem com essa instabilidade, evidenciando-se os contrapontos entre secos e molhados.

No Oceano Atlântico, os inúmeros rios, igarapés, lagos, furos e paranás, e as chuvas formam a torrente aquática amazônica. A navegação pelos rios da Amazônia ensina, umas vezes, um olhar para o inalcançável; outras vezes, um tatear os verdes e os barrancos marginais. As águas soberanas induzem a uma visão difusa com cores que se alternam e se misturam ainda cruas.

O Amazonas, cheio de ilhas de todas as formas e dimensões, oferece no seu curso várias larguras, abunda em ygarapés e paranamerys, que não são mais do que a maior ou menor porção de água do rio compreendida entre duas ilhas ou duas séries de ilhotas. Ora as margens distanciam-se grandemente uma da outra, formando uma vasta extensão d'água, uma baía ou poço, ora se apertam em furos e ygarapés, que, já direitos, já tortuosos, apresentam uma infinidade de pontas, de estirões, e de pequenas enseadas. É assim que em uma viagem que dure algumas horas acontece que algumas vezes se acha o navegante em pleno rio, aparecendo-lhe somente ao longe a fita azul escura dos horizontes, e outras anda a poucas braças das margens, e as árvores da beirada cruzam-se sobre a cabeça, formando uma como abóbada de verdura. (SOUZA, 1990, p. 41)

A vida depende da água, concebida como sobrevivência, como meio de navegação, e como demarcadora de tempo. Nas cidades ribeirinhas, as amarras racionais da urbanidade se perdem em função de uma outra lógica, que considera o tempo das marés, da cor das nuvens, do soprar dos ventos, do esquentar ou o esfriar do sol, além das marcas do relógio industrial e da parabólica. Raimundo Morais (1936, p. 257) defende que o relógio da Amazônia é a água,

porque a água não marca somente as horas, as semanas, os meses e os anos, mas a escassez e a fartura, a alegria e a tristeza. É na corrente dos rios e na superfície dos lagos, que se decidem nossos problemas. De maneira que o homem, em vez de consultar a marcha dos astros na decifração dos enigmas, consulta à altura das águas.

Rios, praias, lagos e igarapés são espelhos permanentes da paisagem, onde narcisos disputam com as belezas naturais. Os territórios, então, estreitam-se ou alargam-se espacialmente, e as águas aprisionadas pelas terras desenham nas esferas líquidas traçados de diferentes formas. A rede hidrográfica pincela o mapa, com cores ora ocres, ora claras, das águas dos rios amazônicos. No capítulo Águas 
brancas, pretas e verdes, do "Anfiteatro Amazônico", Moraes (1936, p. 230-231) elucida sobre as cores as águas da bacia amazônica:

Um fenômeno curioso, e que provoca surpresa na bacia amazônica, é a cor diferente das águas em vários rios. Existem os chamados de água branca, de água preta e de água verde. [...] os rios de água branca [...] Os principais desta série, sem contar com o próprio Amazonas, são o Madeira, o Purus, o Juruá e o Javari. [...] Os mais importantes da série dos de água preta se encontram nas abas do norte do Amazonas, tendo à frente o Negro, o Nhamundá e o Trombetas. Com a denominação de rios de águas verdes acham-se do lado sul os três maiores: Tapajós, Xingu e Tocantins.

Prossegue o autor:

a observação coletiva se resume nisto: os rios que mais trabalham a planície são os de água branca, não somente porque aí estejam suspendendo, mas porque lhe rejuvenesce o quadro botânico. [...] Resumindo: a argila mineral faz a água branca; a terra vegetal, húmica, faz a água preta; e plâncton, marinho ou fluvial, faz a água verde (MORAES, 1936, p. 238-240).

\section{Metáforas da água}

A intimidade e a dependência do amazônico com a água, conforme se anuncia, provocam fortes experiências estéticas, escritores se ocupam em representar a aquosidade da paisagem. Se autores, como Caminha, referem-se à água como elemento de prosperidade e redenção, outros são arautos da dimensão trágica. Euclides da Cunha metaforiza a água como "ruína". Edson Carneiro trata o amazônico como "escravo do rio". Tiago de Mello fala na Amazônia como a "pátria das águas". Giovanni Gallo aponta a "ditadura das águas" no Marajó. Ruy Barata recria Raul Bopp ${ }^{2}$ e afirma o "rio como rua". Dalcídio Jurandir constrói grande parte de sua obra através de metáforas das águas. Portanto, ratifica-se: a compreensão do espaço amazônico ilumina-se com o farol das águas. Elas sinalizam o modo de vida do homem, indicam o comportamento na estação.

\section{A ruína amazônica}

Euclides da Cunha (1999), em “À Margem da História”, no capítulo Terra Sem História (Amazônia), apresenta a imagem mais forte da ruína amazônica, divulgada no Brasil do início do século XX. É um texto provocador para o amazônida, uma vez que a construção da metáfora da ruína deve-se às águas do rio Amazonas, que além de provocar a idéia hiperbólica de espaço indomável, trabalha dia a dia para solapar o território, e não deixa solidificar a história, daí o autor considerá-lo o menos brasileiro dos rios, um tema incrível e atual. Na geografia das terras moldadas pelo rio Amazonas, o que "se destaca é a função destruidora, exclusiva. O enorme caudal está destruindo a terra” (CUNHA, 1999, p. 5).

As terras flutuantes, desgarradas, puxadas pelo rio, se tornam migrantes e, independentes do homem, procuram espaço. À idéia de pátria sem terra, contrapõe-se a de terra sem pátria.

E o Amazonas, nesse construir o seu verdadeiro delta em zona tão remota de outro hemisfério, traduz, de fato, a viagem incógnita de um território em marcha, mudando-se pelos tempos adiante, sem parar um segundo, e tornando cada vez menores, um desgastamento ininterrupto, as largas superfícies que atravessa. (CUNHA, 1999, p. 7)

A imagem da monotonia, que consta em textos anteriores e posteriores ao de Cunha (1999, p. 12), é construída pela presença única da linha horizontal dos rios, que predomina sobre a vertical.

É, sem dúvida, o maior quadro da terra; porém chatamente rebatido num plano horizontal que mal alevantam de uma banda, à feição de restos de uma enorme moldura que se quebrou [...]. E como lhe falta a linha vertical, preexcelente na movimentação da paisagem em poucas horas o observador cede às fadigas de monotonia inaturável e sente que o seu olhar, inexplicavelmente, se abrevia nos sem-fins daqueles horizontes vazios e indefinidos como os dos mares.

As impressões de viagem de Euclides da Cunha levam em conta monografias dos viajantes estrangeiros na Amazônia. Nelas, o autor admite que o espaço seja capaz de fazer tombar teorias preconcebidas e tornar admissível a leitura mítica da Amazônia, pois, reafirmo, não é possível analisar esse território, descartando as explicações sobrenaturais. "Parece que ali a impotência dos problemas

\footnotetext{
2 "Este rio é a nossa rua / Ai o capim pirixi/ Rema Rema deste lado/ Quero ficar espichado/ sobre o capim pirixi / Eu vou convidar a noite/ para ficar por aqui" (Estrofe final do canto XII, do poema Cobra Norato, de Raul Bopp).
} 
implica o discurso vagaroso das análises: as induções avantajam-se demasiado os lances da fantasia. As verdades desfecham em hipérboles" (CUNHA, 1999, p. 4).

A análise da fisiografia amazônica considera a formação ou deformação de ilhas no percurso fluvial. Sobre o Marajó, Cunha reflete sobre a destruição do território e a ilusão espacial, se assegura de Martius e Bates na defesa de seu argumento.

Mas toda essa massa de terras diluídas não se regenera. O maior dos rios não tem delta. A ilha do Marajó, constituída por uma flora seletiva, de vegetais afeitos ao meio maremático e ao inconsistente da vasa, é uma miragem de território. Se a despissem, ficariam só as superfícies rasadas dos 'mondongos' empantanados, apagando-se no nivelamento das águas; ou, salteadamente, algumas pontas de fraguedos de arenito endurecido, esparsas, a esmo, na amplidão de uma baía. A luz das deduções rigorosas de Walter Bates, comprovando as conjecturas anteriores de Martius, o que ali está sob o disfarce das matas, é uma ruína; restos desmantelados do continente, que outrora se estirava, unido das costas de Belém às de Macapá - e que se tem de restaurar, hipoteticamente, em passado longínquo, para explicar-se a identidade das faunas terrestres, hoje separados pelo rio, do norte do Brasil e das Guianas [...] E os resíduos das ilhas demolidas - entre as quais a de Caviana, que lhe foi antiga barragem e se bipartiu no decorrer de nossa vida histórica - vão cada vez mais delineando-se e desaparecendo, no permanente assalto daquelas correntezas poderosas (CUNHA, 1999, p. 5-6).

O rio inconstante provoca a destruição, insiste o autor. As terras caídas prenunciam a ruína, as margens se abatem pelo furor das enchentes e o rio desordenado, revolto, vacilante, destrói, constrói, reconstrói e desgasta, apaga, em horas, o que se erigiu em decênios.

\section{Os escravos do rio}

Edison Carneiro (1946) discute a ocupação do solo amazônico, no início do século passado, a partir do verso de Raul Bopp, "esse rio é nossa rua". Para ele, o habitante não ultrapassa as terras banhadas pelo grande rio e pelos inúmeros afluentes e confluentes, devido à facilidade de locomoção na árvore hidrográfica e impenetrabilidade da floresta. Todavia, esses povoados construídos nas margens são precários e os territórios ocupados correm riscos constantes de transmutação, devido a alguns fatores naturais como: ser levado pelas águas, sofrer danos com a erosão e com as alagações periódicas aspectos abordados por Euclides da Cunha de forma mais trágica.

Nos arraiais, nas vilas e nas cidades ribeirinhas, a canoa, aportada na frente das casas, representa um ícone de sobrevivência. O rio alimenta, transporta, enriquece, protege o homem: toda a população ribeirinha vive do e no rio, submissa e dócil aos seus caprichos, é "escrava do rio":

São povoações longitudinais, que acompanham o rio, espelhando-se nele, em vez de penetrar a terra firme e criar condições de vida autônoma, sem tanta dependência do meio físico. Estas povoações não fixam o homem, dispersam-no. São estações - no máximo estações terminais onde o amazônida amarra a sua canoa ao fim da labuta diária. Os vizinhos estão rio abaixo ou rio acima, ou sobre as águas do rio, e é sobre a superfície líquida que se dão os encontros, que se efetuam os negócios, que se transmitem as notícias. (CARNEIRO, 1946, p. 9)

\section{Ditadura das águas}

Giovanni Gallo ${ }^{3}$ (1980, p. 61), igualmente, frisa a regência das águas fluviais:

Quem manda aqui não é presidente da república, não é governador, não é prefeito. Aqui domina uma ditadura absoluta e incontestável, não baseada na Constituição ou nas Forças Armadas. É um dado de fato, quem manda é a água. É a água quem dá o sustento e cria as dificuldades, consola e leva ao desespero, condiciona a saúde, o trabalho, a vida da gente: sem levantar a voz, sem violência, mas implacável e total. [...] As estações do ano, aqui têm um nome exclusivo: água, lama e seca.

Gallo, em entrevista (2000), indica, que, apesar da ditadura, o homem encontra formas de resistência à imposição da natureza, ou melhor, de convivência com as estações - de cheias, de lama e de seca -, inventa meios de fazer as travessias, cria uma arquitetura apropriada ao espaço, como as casas

\footnotetext{
${ }^{3}$ Giovanni Gallo (1927-2003), ex-padre italiano, morou mais de trinta anos no Marajó, dedicou-se à pesquisa das formas de vida desta região, criou $O$ Museu do Marajó (ver www.museudomarajo.com.br) - uma das mais importantes instituições de estudo sobre a cultura amazônico-marajoara, hoje ligada ao Museu Paraense Emílio Goeldi.
} 
caneludas ou as marombas. O trágico imposto pela natureza é, muitas vezes, aliviado pela força criativa do homem. $\mathrm{O}$ pesquisador ainda investe na diferença entre os dois marajós e indica essa diversidade nas águas grandes, abordando também questões da estação da pesca.

É a água quem domina, quem regula a nossa vida. Eu falo do Marajó nosso. Você sabe que tem dois marajós, completamente diferentes. Marajó oriental é a área dos campos do Marajó, que são alagadiços; de Muaná para cima, é a área de mato, floresta, tem uma vida completamente diferente e não tem nada a ver com o nosso. Aqui, a vida do campo tem uma expressão diferente.

Bem, nesta área aqui, a água tudo condiciona, porque você tem uma estrada, a estrada é ótima no verão, no inverno não presta mais. Uma casa, a casa que você faz, até quando a água não existe condiciona, aquela fotografia da capa do meu livro, vê aquela casa caneluda, que sentido tem? Tá no seco, mas ela te lembra, quem manda aqui é a água: 'dentro em pouco, eu vou chegar e vou condicionar vocês'. Assim, a vida, a pesca é ligada com a água. Agora, aqui, vamos para a destruição total, porque não tem mais controle de pesca, não tem mais a estação de pesca, abertura de pesca. Naquele tempo, vinha o governador. Eu me lembro, vinha o dia da abertura oficial da pesca. Agora não, eles pescam no tempo da piracema, vão praticamente destruindo tudo. Então, é uma vida social também, que é determinada pelas águas, água alta, água baixa, se pesca ou não se pesca.

A vida da fazenda, a fazenda é estruturada na base da água, não é a fazenda que está na estrada, ou o campo, que deve ter uma parte baixa, que tenha mais possibilidade de ter uma reserva de água durante o verão, a parte alta para agasalhar o gado quando a água é fresca. Uma coisa que o outro não tem. Nós já temos uma estrutura de fazenda em função da água que vai e que vem, e, depois, a pesca que vai num certo período e no outro. É isso, é assim tudo condicionado pela água.

\section{A pátria das águas}

Tiago de Mello (2002) ratifica o condicionamento humano às águas, porém denuncia a ação predatória do homem em relação à natureza, apresenta, através do poético, dados da devastação, da história amazônica, de entes protetores. O poeta enumera as fontes da matéria dessa pátria das águas:

Da altura extrema da cordilheira, onde as neves são eternas, a água se desprende e traça um risco trêmulo, na pele antiga da pedra: o Amazonas acaba de nascer. A cada instante ele nasce. Descende devagar, sinuosa luz, para crescer no chão. Varando verdes, inventa o seu caminho e se acrescenta. Águas subterrâneas afloram para abraçar-se com a água que desceu dos Andes. Do bojo das nuvens alvíssimas, tangidas pelo vento, desce a água celeste. Reunidas, elas avançam multiplicadas em infinitos caminhos, banhando a imensa planície cortada pela linha do equador. [...] Aqui está a maior reserva mundial de água doce, ramificada em milhares de caminhos de água, mágico labirinto que de si mesmo se recria incessante, atravessando milhões de quilômetros quadrados de território verde. (MELLO, 2002, p. 15)

Na mistura das águas de diferentes origens, Mello destaca o tema da chuva, uma vez que o teto amazônico é um dos lugares onde mais chove no mundo. O índice pluviométrico anual é de $3.000 \mathrm{~mm}$. Os homens respeitam as águas celestes, as forças dos temporais derrubam árvores, as arrasta para correnteza, e põem em perigo as embarcações. O tempo de chuva na região é o de sempre: em alguns momentos chove mais incisivamente, em outros, estia, e as cores pluviais variam entre nuances pretas, brancas, lilases, arroxeadas.

Ela chega ninguém sabe é quando. Chega no meio da noite, o corpo se encolhe na rede com a friagem dela o sono se embala na cantiga que ela inventa com as palmas das inajazeiras. É quando a gente vai atravessando o rio, a escuridão rasgada de relâmpago de uma margem à outra, iluminando a face enfurecida das águas [...]. A chuva roxa é terrível, porque - na claridão do pleno meio-dia ou na luz suave do começo da manhãzinha - todas as nuvens alvíssimas que passeiam vagarosas e solenes pelo campo da luz são de repente atraídas por um grande e rosado funil, que se abre bem na cabeceira do rio. Todas (eu estou dizendo todas) as nuvens que, luminosas demais, cobrem o silêncio da floresta e vão avançando, de começo vagarosas, depois céleres, se vão desmanchando pelo caminho ao encontro de um misterioso chamado. Em brevíssimos instantes, a extensa e delicada nuvem lilás começa a estender-se, esgarçada e suave: e dela começa a cair uma água fininha, mas que dói como lâminas afiadas, quando bate no teu rosto, te fustiga as pálpebras e atravessa, como espinhos, a tua roupa. Por sorte, ela é dessas que não demoram, é chuva de verão. (MELLO, 2002, p. 48-49)

A poética das águas de Mello, como as demais, indica que o homem segue as ordens do rio. Os ciclos econômicos são definidos pelas enchentes e pelas vazantes. O da vazante é de fartura das 
plantações, das colheitas, das pescarias, e o tempo da enchente, ao contrário, das calamidades e das misérias: o peixe se esconde, as plantações são destruídas. E acrescenta:

o gado tem que ser levado para as alturas da terra firme ou então é reunido às pressas na maromba, exíguo curral erguido sobre os esteios acima das águas, as sucurijus enormes espreitando; o soalho das casas fica submerso, as cobras se aproximam no faro de animais domésticos e de crianças também. $\mathrm{O}$ homem fica à mercê do rio. Mas não desanima: espera pela vazante e alteia o soalho, e aproveita depois a terra enriquecida pela enchente (MELLO, 2002, p. 27).

\section{A ficção atinge a dimensão mítica}

As fábulas de Eneida [de Moraes] e de Raymundo Moraes, Dalcídio Jurandir e de Rita Abdon, entre outras, constroem cosmogonias do Marajó e da pororoca, além de traduzirem a condição inescapável da águas.

Em Soure ${ }^{4}$, conta-se a história do Toco, que incide na questão da destruição, da catástrofe nas águas marajoaras. Ele é um habitante do Paracauari, rio que passa em frente daquele município. Dizem que o Toco veio do Maranhão, encantou-se pela beleza da ilha e, por inveja, impôs a morte por afogamento de seus habitantes. Um jogo de espelhos conduz à morte, explica a origem. Na literatura, há um repertório considerável de personagens em que a relação especular ocasiona a morte. Dorian Gray não resistiu ao constatar a perda da sua beleza. Narciso, na versão mais conhecida, ao contrário, encontra a morte ao apaixonar-se por si mesmo. No caso do Toco, a comparação não acontece com um retrato, nem com sua própria imagem, ele se encanta pela a beleza do outro. Espelhar-se nas águas e não se ver tão belo quanto o outro provoca inveja. E o Marajó é castigado. Beleza e morte, uma dupla contraditória. Registro uma versão exemplar contada por Rita $\operatorname{Abdon}^{5}$, que constatou o mítico na própria pele, com a morte de um familiar.

A história do toco é uma lenda muito espantosa, porque a gente já teve oportunidade de ver, e pra gente que acredita, e tem muitos que não acreditam, mas passam a acreditar, como eu que não acreditava, mas tive a oportunidade já de ver. Numa viagem, que vinha de Belém para Soure, vinha pelo Camará, quando todo mundo se espantou do toco. Então, toco é um pau, um pedaço de pau que ele vem em pé dentro d'água, sempre ele anda contra a maré. Ele sempre aparece nas águas grandes, em março, é mais freqüente ver ele, mas, de vez em quando, aparece nas outras águas grande, porque as águas maiores, que nos temos, são as águas de março. Então, contam os antigos, que toda vez que o toco passa, sempre morre uma pessoa.

Ele caminha em direção da parte da ali, do Garrote até ali, no fim das fazendas. Garrote é pra lá, pra lá, no início. Então, ele caminha aqui, ele entra no rio Paracauari e vai embora. Diz que ele visita todas estas fazendas, aí ele fica pra lá. Depois, ele retorna, às vezes, passa dois meses, ou um mês, ele retorna. Quando ele retorna, torna a desaparecer outra pessoa. Aí, o pessoal se esquece do toco, quando é depois, ele torna a aparecer, assim vai.

[...] Perdi um irmão com 17 anos, e ele ia até servir, já ia pro alistamento militar, quando a minha mãe, muito preocupada, disse que não ia deixar ele ir, porque todo ano, mês de julho, quando esse toco passava, morria uma pessoa. Ele ia embora dia dois de julho. Quando foi dia primeiro, meus irmãos chegaram assustados, dizendo que tinham visto o toco lá na ponte. A mamãe disse: 'agora vocês vão parar de tomar banho'. Aí, quando foi no outro dia, duas horas da tarde, meu irmão foi tirar umas varas, já pra banda do Mata Fome, que eles chamam aqui em Soures. Ele não conseguiu atravessar um igarapé que tinha, e ele morreu afogado. A minha mãe disse: "É, agora, eu passei a acreditar na lenda do toco, porque ele morreu". Quando foi no final das férias, ele tornou a passar. Aí, morreu dois rapazes afogados lá na ponte, no mesmo ano, nesse ano.

Meu irmão tem 24 anos de morto, e nesse ano que o toco passou, tanto ele morreu quando ele passou, quanto quando ele voltou. E não custou muito a passar, porque, às vezes, ele fica por estas fazendas, passa uns três meses, aí torna a passar. Quando ele passa aqui pra fazenda, quando ele desce ali o Paracauari, ele não retorna logo não, às vezes, passa dois meses, às vezes não, ele retorna logo. E ele só anda contra a maré.

É um toco de madeira, a gente tem a impressão que é um pau cortado. Um pedaço de pau, de um metro, cortado, só que é um toco assim, bem volumoso ele, bem grosso. Agora, ele não vai caído na água, ele vai todo tempo em pé, engraçado, interessante. Eu já tive oportunidade de ver, eu nunca tinha visto, agora, quando vinha do Camará, que eu tive. Todo mundo grita: 'olha o toco,

${ }^{4}$ É a cidade mais conhecida do Marajó, devido à infra-estrutura turística e as fazendas de gado, o município está situado na região do Arari.

${ }^{5}$ Rita Maria dos Santos Abdon, moradora de Soure, trabalhava no ramo alimentício, tinha 43 anos no momento da pesquisa (2001). 
olha o toco'. Aquele medo assim que dá na gente de olhar, né? Mas, a curiosidade é maior. Olhe, eu não sei como chegou aqui no Marajó, mas o pessoal fala que isso é um encanto, assim como tem a cobra grande também, dizem que é um encanto, mas eu nunca tive oportunidade de conversar com gente mais antigo que eu, pra mim saber. Nunca fui a fundo nisso, mas todas essas coisas que aparecem assim, diz que são encantados, né?

Os ruídos dos jacumãs ${ }^{6}$. A cosmologia do Marajó conta do amor não correspondido de Nonhon (a ilha do Marajó) por Surnizuno (o rio Amazonas). Uma luta passional entre personagens míticas origina o Marajó e as "madrugadas sangrentas".

Lembro de Tungurana, pai de Surnizuno, exigindo de Nunó - a lua - que derramava somente leite na boca de Paqueima - a madrugada - que fizesse também auroras sangrentas. Surnizuno, filho de Tungurana, depois se chamou Solimões, Maranhão e finalmente Amazonas. Isto tudo acontecia naquele tempo, quando deuses, rios, florestas e pássaros falavam, sentiam e agiam, eram gente.

Surnizuno despertou o amor de Nonhon, a virgem que guardava em si os tesoiros da terra e ela, um dia, cheia de amor, beijou-o na boca. O beijo de Nonhon não interessava Surnizuno porque ele não a amava; a carícia enfureceu-o, a ousadia irritou-o e assim, de sua tremenda cólera, surgiu a pororoca. Como castigo pela audácia que tivera, Capú transformou o corpo de Nonhon numa ilha: a do Marajó. (Não se beija impunemente o Amazonas). Sobre o corpo de Nonhon feito ilha, Paqueima teve ordem de realizar os desejos de Tunguragua: enfeitá-la com madrugadas sangrentas (ENEIDA, 1954, p. 16-17).

\section{A pororoca não se acaba}

Criada pela fúria do Amazonas, ou pelos pulos e cambalhotas de três pretinhos, ou ainda pelos botinhos que queriam ver a mãe, a pororoca associa-se às dimensões catastróficas do rio. Apresento três versões recolhidas em suporte escrito. A narrativa de Moraes (1937) nomeia os mais diferentes fenômenos relacionados à água e pesquisa as influências da lua nas marés.

Antigamente a água era serena, quieta, mansa. As canoas à vela e a remo navegavam sem o menor perigo. A Mãe d'Água morava com a filha mais velha, a Baía do Marajó, casada com o boto Tucuxy. Uma noite, na ocasião da janta, ouviram-se gritos no terreiro; os cães latiram, as galinhas cococorocaram. O que é, o que não é? Tinham furtado Jacy, a canoa de estimação da família. Depois de haverem remexido céus e terra sem encontrar a veleira, a Mãe d'Água convocou todos os filhos: Repiquete, Correnteza, Estoque, Rebojo, Remanso, Vazante, Enchente, Maré Morta, Maré Viva. Tratava-se de meterem a pique a embarcação desaparecida.

Lavrada a sentença, passaram-se anos sem que a Jacy fosse encontrada. Ninguém a via. Por certo se achava escondida em lugar, onde não chegavam aquelas forças dinâmicas da Natureza. Chamaram-se então todas as figuras domésticas, além das já convocadas para um grande conselho. Reunida a tribo, na qual surgiram parentes longínquos, como Lagos, Lagoas, Igapós, Igarapés, "Sacados", Rios, Barras, Baías, Sangradouros, Enseadas, Angras, Radas, Golfos, Fozes, Canais, Estreitos, Panamás, Córregos, Poções, Peraus, foi discutido o caso, ficando provado ser necessário criar um elemento mais poderoso além dos que já existiam e que fosse, algumas vezes no ano, procurar a canoa furtada.

O marido da Baía do Marajó lembrou-se de fazerem a pororoca, umas três ou quatro vagas fortes, que entrassem por tudo quanto era buraco do litoral, que houvesse nas redondezas e fossem quebrando, derrubando, escangalhando, naufragando, espatifando, tudo encontrado ao largo e pelas beiradas, até destruir Jacy e o ladrão que a levara. Ficou então incumbida a caçula da Mãe d'Água, a Maré de Lua, rapariga travessa, namoradeira, dançadeira, brigadeira. E de repente, nas syzygias de equinócio, do novi e plenilúnios, meia dúzia de vagalhões tremendos, empurrados pela formosa cunhatã, surgiram em certos lugares, invadindo rios, repartindo ilhas, derrubando barrancos, afundando barcos, ameaçando gaiolas e afugentando paquetes. Era a pororoca. Mas, sempre que a Maré de Lua vai visitar a família, na época das quadraturas, quando ela, a caçula, está de folga, a conversa é desanimadora. Ninguém sabe da Jacy. "Pois, então, continue arrasando tudo", diz a fungar o danado do boto Tucuxy. É por isso que a pororoca não se acaba. (MORAES, 1937, p. 179-181).

É conhecida a história dos três pretinhos, que, às vezes, são transfigurações de três botinhos, frutos do amor de uma índia com um boto, encantado em humano. O mito de origem da pororoca, a seguir, é muito contada no município de São Domingos do Capim, no Pará:

Há muitos anos nas margens do rio Capim, existia uma grande tribo dos índios Tambés, nessa tribo vivia um cacique muito forte e valente chamado "Pirajauara", que também era pescador. Ele

\footnotetext{
${ }^{6}$ Referência à crônica Ouçam os ruídos dos jacumãs, de Eneida (1954).
} 
tinha uma filha muito bonita cujo nome era "Flor da Noite", de cabelos lisos e muito longos. Essa filha, assim como o pai, gostava de estar às margens do rio, nas praias. Todos os dias quando o sol se punha ela ficava observando. Certa vez em uma noite de lua cheia a indiazinha adormeceu na praia, e foi acordada com um barulho que vinha do rio, e de repente viu uma pessoa toda vestida de branco com chapéu de palha na cabeça, saindo das águas. No primeiro instante ela teve medo, mas o belo rapaz aproximou-se e disse: "Não tenha medo, não vou lhe fazer mal" e assim eles passaram a conversar. Esse encontro aconteceu por diversas vezes, sempre em noite de lua cheia; ele saia das águas e os dois ficavam conversando e assim passaram a namorar. Ela então ficou grávida. Muitas luas se passaram, e finalmente "Flor da Noite" deu à luz, porém, para surpresa de todos, em vez de três crianças, nasceram três botinhos. Ela ficou muito assustada, pois não podia criá-los. Então, embora muito triste, a mãe resolveu soltá-los nas águas para que não morressem. E com o passar dos anos, ao sentirem saudades de sua mãe, os três botinhos unem-se à procura dela, e vem saltando sobre as águas, fazendo uma grande onda, que se estende até as margens do rio, derrubando árvores e virando embarcações. Os três botinhos são chamados de três pretinhos da pororoca. ${ }^{7}$

A obra do escritor marajoara Dalcídio Jurandir ${ }^{8}$ é uma espécie de cartografia da cultura marajoara, daí ser um dos autores que melhor referencia as águas e as terras amazônicas. Uma infinidade de imagens traz diferentes semânticas, que constroem cenários de salvação ou de perdição do mundo da seca, das enchentes e dos atolados. O romancista registra outra versão mítica da narrativa dos três pretinhos, para explicar o fenômeno da pororoca:

É três pretinhos que vêm pulando na espuma da maresia, brincando, fazendo pirueta tanto que, quando a ribanceira tem pedra, eles atravessam mergulhando. Mudam de beira e vão aparecer mais adiante na cambalhota. Diz-que os pretinhos na volta vêm por terra. Por isto é que a pororoca não volta. [...] Um movimento de assombro e de pânico assaltou o menino na montaria sem direção. A onda mergulhou com os três pretinhos invisíveis, para estourar adiante, subindo, com o ímpeto e a velocidade de uma cobra boiúna em fuga. (JURANDIR, 1994, p. 340-341)

José Arthur Bogéa (2003), em Bandolim do Diabo (Dalcídio Jurandir: fragmentos), seleciona por tema metáforas recorrentes na obra de Jurandir e as apresenta por meio de excertos dos dez romances. Em Haver d'água, o pesquisador recorta:

Antônio se agitando no chão principiou a falar alto, repetindo pedaços de estória, nomes de bichos, rios, tempo de marés, gritando ei vem, a pororoca, ei vem o haver d'água (JURANDIR, 1960, p. 252).

Entre as muitas metáforas referentes às águas, apresento ainda a luta entre o rio, a seca e a fuga de todos os habitantes das águas fluviais, inclusive da cobra grande. A descrição do abandono dos seres e a súplica do rio agonizante representam uma das mais belas passagens da obra dalcidiana:

Era a queixa de um rio à cobra, sua mãe que o abandonava. $\mathrm{O}$ rio se lamentava soturnamente no meio do mato. Cobra grande não me abandone. A terá crescia na água. O rio secava. Os estirões, largos outrora, se estreitavam, se estreitavam e as margens se fundiam balançando nas redes dos cipoais. Cobra grande não me abandone. A cobra dormia no fundo do rio e de repente acordou, era meia noite e deu um urro: vou-me embora pras águas grandes. Então os peixes, todos os bichos, os caruanas, a alma dos afogados, os restos dos trapiches, as montarias também seguiam pras águas grandes. Os restos de cemitério que tombavam nas beiradas também partiam pras águas grandes. Adeus, ó limo da cobra grande, adeus ó peixes, adeus, marés, tudo vai embora pras águas grandes. Até a lama há de partir, os anigais, as velhas guaribas, tudo seguindo pras águas grandes. O rio se queixava, se queixava, secando sempre: não me abandones, meã cobra grande, me amamenta nos teus peitos, vomita em meu peito o teu vômito, enche os meus poços, alaga as margens, quero viver, quero as marés, mãe cobra grande. Ninguém ouvia o agonizante rio. (JURANDIR, 1994, p. 133-134)

Em Aquanarrativas: uma leitura de Chove nos campos de Cachoeira, de Dalcídio Jurandir, Paulo Nunes ${ }^{9}$ estuda as imagens das águas recorrentes na obra do escritor marajoara e conclui:

Nas águas grandiosas, rios e lagos convivem com a mesma força. Assim, o narrador não dá importância maior a este ou aquele fenômeno. Temos então o Arari, o Maguari, a Baía do Marajó, todos reunidos no mesmo manto poderoso das águas. Se compararmos com o culto marial católico, todos os lagos e rios são recorrências de uma mesma água: Mãe de todos, a

\footnotetext{
${ }_{8}^{7}$ Disponível on-line em: <www.amazonia.com.br/portal>. Acesso em: 01 dez. 2006.

${ }^{8}$ A obra do escritor compõe-se de dez livros do Ciclo do Extremo-Norte - Chove nos campos de Cachoeira (Rio de Janeiro: Vecchi, 1941), Marajó (Rio de Janeiro: José Olympio, 1947), Três casas e um rio (São Paulo: Martins, 1958), Belém do Grão Pará (São Paulo: Martins, 1960), Passagem dos Inocentes (São Paulo: Martins, 1963), Primeira manhã (São Paulo: Martins, 1968), Ponte do Galo (São Paulo: Martins, 1971), Chão dos Lobos (Rio de Janeiro: Record, 1976), Os Habitantes (Rio de Janeiro: Arte Nova, 1976), Ribanceira (Rio de Janeiro: Record, 1978) - e um do Extremo-Sul - Linha do Parque (Rio de Janeiro: Vitória, 1959).

${ }^{9}$ Fonte: e-mail pessoal.
} 
"Santa Maria da aquonarrativa". Não interessa se é Perpétuo Socorro, Nazaré, Lourdes ou Fátima: todas são várias e una mãe de Deus.

Vocabulário dos termos referentes às águas nos textos estudados

Angra: s.f. pequena baía ou enseada, ger. com ampla abertura e junto a costas elevadas a gram dim.: angreta ’o etim lat.tar. ancrae, árum ou angrae, árum 'intervalo ou espaço entre duas árvores', com especialização de sentido; ver sinonímia de baía (Houaiss Eletrônico).

Aquonarrativa: expressão cunhada pelo escritor Paulo Nunes (2001), em referência à obra do escritor Dalcídio Jurandir, no estudo Aquonarrativa: uma leitura de Chove nos campos de Cachoeira, para referir-se às narrativas em a água tem o domínio na fábula, contrapondo-se a expressão sedenarrativa para expressar a ausência desta, como no caso da literatura do ciclo da seca do nordeste.

Barra: s.f. 1 GEO MAR entrada de um porto, entre duas porções avançadas de terra firme 2 p.ext. GEO entrada de baía 3. GEO B banco ou coroa de areia ou de outros sedimentos que os rios trazem e depositam nas suas bocas 4 GEO MAR B local em que um rio deságua no mar ou em lago; desembocadura, foz (Houaiss Eletrônico).

Delta: foz caracterizada pela presença de ilhas de aluvião, geralmente de configuração triangular, assentadas na embocadura de um rio e que forma canais até o mar. [aluvião 1 depósito de cascalho, areia e argila, que se forma junto às margens ou à foz dos rios, provenientes do trabalho de erosão das enchentes ou enxurradas. 2. Inundação, cheia, enxurrada, enchente, alúvio]. (Aurélio Século XXI. Eletrônico).

Estoque d'água: ponta de corrente que vara o caudal em sentido obliquo. É determinado pelo remanso, que, depois de refluir à massa fluvial, volta a fazer parte dela. Penetra então bruscamente na toalha, gerando uma confusão de diretrizes. Quando o prático não é bastante hábil para evitar o estoque d'água, o gaiola [tipo de embarcação amazônica] desgoverna com o choque recebido à proa e muitas vezes enfia-se na margem contraria, vara uma praia ou sobe num cabeço de pedra. É um fenômeno hidrográfico dos rios velozes (MORAES, 1931, p. 173-174).

Golfo: porção do mar que entra fundo pela terra e cuja abertura é muito larga. Golfão. (Aurélio Século XXI. Eletrônico).

Igapó: floresta alagada. Charco onde vegeta a mata aquática. Lagos de água escura e transparente, recobertos de selva. Em geral não se vê um raio de sol no igapó. Tudo por cima é galho e folhagem. A abobada é verde. Os grandes troncos de árvores mergulham na linfa cristalina, porém negra. Os peixes do igapó são especiais. É o jejú, o tucunaré, o puraqué, a piranha, o tamuatá, o acari, o tambaqui. Dos quelônios, o que mais gosta do igapó é o matamatá (MORAES, 1931, p. 27-28).

Igarapé: caminho de canoa, segundo a tradução precisa do tupi para o português. Riacho amazônico, ribeiro, curso em miniatura que tem, como os grandes, todas as características fluviais. Principia sendo central, oriundo de hinterlândia, por mais insignificante que seja o seu curso; tem cabeceira, declive, voltas, afluentes gitos [pequenos] e foz. Não entra e sai no mesmo rio como os paranás. [...] Assim como na dos lagos, nenhuma canoa lhe pernoita na boca, onde se encontram batendo, fungando, mergulhando, nadando, jacarés, botos, sucurijus, poraquês, piraíbas que aí devoram os peixes miúdos erradios. De noite, a foz dum igarapé é um verdadeiro inferno, um lugar pavoroso das nossas lendas, tais os ruídos dantescos que se ouvem (MORAES, 1931, p. 28). Igarapé, garapé, guarapé, [iara'pe < i'ara 'canoa' + pe 'caminho' caminho da gente]. Pequeno rio que corre entre duas ilhas ou entre uma ilha e a terra firme; canal natural que liga dois trechos mais ou menos mais ou menos próximos de um mesmo rio (CUNHA, 1999, p. 151). Comumente, costuma-se chamar a espécie de riachos correntes, normalmente estreitos e não muito profundos, com um caminho protegido pela mata, o que impede a penetração do sol e ocasiona, em certas partes, águas gélidas.

Jacumã: remo indígena em forma de pá (ASSIS, 1992, p. 98). Governo de uma canoa com um remo de uma mão numa das extremidades. Ir no jacumã: pilotar, dirigir uma canoa com um remo de mão. Etim. tupi (MIRANDA, 1968, p. 44).

Maré: elevação e abaixamento periódico das águas do mar. Mas até onde chega esse fenômeno, pelo Amazonas adentro? É isso que o autor deseja informar aqui, visto como sobre o assunto reina o maior desacordo, a maior confusão, mesmo entre escritores notáveis e até entre sábios. Uns marcam Santarém, como seu ponto terminal; outros vão até Óbidos. A verdade, observada por quem escreve estas 
linhas, é que a maré sobe até Parintins, no mês de outubro, quando o Amazonas, quase parado, perde toda a sua força. Ela não tem fluxo, aí quando enche, isto é, não corre para cima - tufa apenas. De bordo, amarrado o navio ao porto, vê-se no barranco uma estreita faixa molhada de dois dedos, quando a maré vazou. De Parintins para baixo observa-se a maré no caldeirão, que é um furo transversal ligando o Paraná do Bom Jardim ao Amazonas, fluindo e refluindo, queremos dizer, correndo p'ra dentro e p'ra fora sob a ação da lua. Ora, o Caldeirão é um furo que fica à margem esquerda do Amazonas, 42 milhas a jusante de Parintins e 56 a montante de Óbidos. Se a maré se faz sentir nele, embora no tempo seco, no mês de outubro, fluindo e refluindo, é porque ela remonta muito acima. Nestas condições, que fique como padrão: Parintins é o derradeiro ponto em que se observa a maré Amazonas adentro, ou sejam, 618 milhas acima de Belém, navegando pelos paranás (MORAES, 1931, p. 59).

Maromba. Bras. AM Jirau onde se põe o gado por ocasião das cheias (Aurélio. Século XXI. Eletrônico). Em algumas cidades amazônicas, às vezes, corresponde a uma espécie de assoalho móvel, que sobe, conforme a altura das águas. Este processo, no caso, acontece não somente no local onde se coloca o gado, mas também nas moradias dos habitantes do lugar no período de cheia.

Mondongos: extenso balcedo entremeado de aningais, de solo afofado e atolento de vegetação pujante e cerrada, difícil de romper-se, coberto durante o inverno por quatro a oito palmos d’água e que só seca e endurece nas últimas semanas do verão. § Enormes aningais, crescendo sobre perigosos tereterês, em compridos e largos cordões, de solo excessivamente atolentos, coberto por espessa camada de raízes aéreas das aningueiras e de folhagem seca das mesmas (MIRANDA, 1968, p. 57). [Aninga: planta herbácea, abundante nas margens pantanosas dos lagos, rios e depressões de várzeas, é muito comum às ilhas flutuantes da Amazônia. As flores e os frutos servem para isca na pescaria, e, segundo o povo, é medicinal (ASSIS, 1992, p.16).]

Paraná: braço de um rio caudaloso separado da artéria principal por uma ou por diversas ilhas. Paraná-mirim (Parana-miry) braço estreito de um grande rio. Etim. tupi paraná rio (MIRANDA, 1968, p. 64) [o mesmo que paranamerys].

Poção: Lugar nas Ilhas de Dentro (Furos de Breves) onde desembocam vários canais. Claros redondos no labirinto fluvial. Poção dos Macacos. Poção da Olaria (MORAES, 1931, p. 98).

Pororoca: s. f. Regionalismo: Brasil. 1. Rubrica: geografia. Grande onda de alguns metros de altura que ocorre, em certas épocas, em rios muito volumosos, especialmente o Amazonas, perto da sua foz, e que destrói tudo que encontra à sua passagem, causando grande estrondo e formando atrás de si ondas menores; mupororoca. Banzeiro (Houaiss Eletrônico). Hoje, o fenômeno é esperado, em alguns municípios paraenses, especialmente em São Domingos do Capim, não só pelos habitantes do lugar, mas por surfistas do mundo inteiro.

Rada: s.f. enseada ou porto, abrigado por terras ger. elevadas d etim fr. rade (1474) 'parte do mar que penetra na terra e proporciona aos barcos ancoradouros abrigados de vento e ondas'; 'bacia natural ou artificial de vastas dimensões com uma saída para o mar, onde os navios ancoram' a sin/var ver sinonímia de baía e porto (Houaiss Eletrônico).

Rebojo: Funil d'água que a corrente abre sobre cabeços de pedra, troncos de árvore fincados no álveo, ou nos encontros de caudais na confluência dos rios (MORAES, 1931, p. 114).

Remanso: água dos rios que corre, na beirada, em sentido contrário do caudal em virtude de pontas de terra, fins de praias, enseadas, onde o ângulo morto provoca uma espécie de refluxo fluvial (MORAES, 1931, p. 116).

Repiquete: sinal de enchente, acima do estuário amazônico, onde não predomina mais a força da maré atlântica. Primeiras manifestações anuais das cheias. Enxurrada. Lençóis turvos, de linfa. Água nova que invade a água transparente, quieta, manchando de placas barrentas a toalha liquida (MORAES, 1931, p. 116).

Sacado: corte que a corrente faz para abreviar o curso do rio. Seccionamento de uma península fluvial pelo istmo. O caudal, depois de passar num ponto, dá uma, duas, três voltas e vem passar, em sentido contrário, renteando a mesma margem. Quando sucede fazer-se enseada nos dois lados do istmo, a água corrói, fura a terra, abandona o caminho velho, que fica morto como um lago, e abre passagem nova. Em geral os rios de mais sacados são os de água preta, de menor velocidade. O Pauhiny, afluente do Purus, parece conter o maior número, segundo observação direta do autor (MORAES, 1931, p. 123).

Sangradouro: s.m. 2 canal, sulco pelo qual se desvia parte da água de um rio, de uma fonte ou na barragem de um açude ou de uma represa, pelo qual escoa a água excessivamente acumulada; sangrador 4 B vala ou conduto para dar saída a líquidos, dejetos etc.; sarjeta, escoadouro, bueiro 6 PI boqueirão, garganta entre serras, que se inunda por ocasião das enchentes 7 B S. canal natural que liga dois rios, dois lagos, ou um rio a um lago a sin/var sangradoiro, sangrador (subst.); ver também sinonímia de rego (Houaiss Eletrônico). 


\section{BIBLIOGRAFIA}

ASSIS, Rosa. O vocabulário popular em Dalcídio Jurandir. Belém: UFPA, 1992

AURÉLIO Século XXI eletrônico.

BOGÉA, José Arthur. Bandolim do Diabo. Belém: Pakatatu, 2003.

CAMINHA, Pero Vaz. A carta. Lisboa: Comissão Nacional Para as Comemorações dos Descobrimentos Portugueses, 2000.

CARNEIRO, Edison. A conquista da Amazônia. Coleção Mauá. Ministério da Viação e Obras Públicas, 1956.

CUNHA, Euclides. À margem da história. São Paulo: Martins Fontes, 1999.

ENEIDA [de Morais] Ouçam os ruídos dos jacumãs. In: Cão da Madrugada. São Paulo: José Olympio, 1954.

GALLO, Giovanni. Marajó, a ditadura da água. Belém: Secult, 1980.

HOUAISS eletrônico.

JURANDIR, Dalcídio. Belém do Grão Pará. São Paulo: Martins, 1960.

JURANDIR, Dalcídio. Chove nos campos de Cachoeira. Belém: Unama, 1998. [Ed. crítica. Rosa Assis] JURANDIR, Dalcídio. Três casas e um rio. 3.ed. Belém: Cejup, 1994.

MELO, Tiago de. Amazonas, pátria das águas. Rio de Janeiro: Bertrand Brasil, 2002.

MORAES, Raymundo. Aluvião. Rio de Janeiro: Civilização Brasileira, 1937.

MORAES, Raymundo. Anfiteatro amazônico. São Paulo: Melhoramentos, [193-?].

MORAES, Raymundo. País das pedras verdes. 2.ed.. Rio de Janeiro: Civilização Brasileira, 1931.

NUNES, Paulo Jorge. Aquonarrativa: uma leitura de "Chove nos campos de Cachoeira", de Dalcídio Jurandir. In: FARES, Josse; NUNES, Paulo. Pedras de Encantaria. Belém: Unama, 2001.

SOUZA, Márcio. Breve história da Amazônia. São Paulo: Marco Zero, 1994.

<www.amazonia.com.br/portal> Acesso em: $01 \mathrm{dez} .2006$.

<www.museudomarajo.com.br> Acesso em: 01 dez. 2006. 